\title{
Digital Wallet V/S Traditional Banking: An Analysis on Customer Preference
}

\author{
Vaishnavi.S, Shreyas. Sumesh.Menon, Vishnu Priya.B, C.Dhanalakshmi
}

\begin{abstract}
Banking system are considered as the bank bone of any developed or developing economy. Banks are the financial institution which accepts deposits from people with surplus fund and directing them to the persons who are in need of money. In the course of this process they boost the economy by infusing necessary fund into the economy. The difference of the interest paid on deposits and interest earned on loans are the earnings of the bank. Traditional banking refers to going to banks to deposit fund, to withdrew fund or to for applying for loans. To put it simple in traditional banking system if we have to do any sort of banking activity we have approach branches of the respective banks. Digital wallet also known as e-wallet allows the user to make transactions from the comfort of their home and even provide loans to a certain amount without even visiting any physical institutions. These digital wallets will be linked to any banks where the customer holds an account. We are analyzing the wheatear the customer prefer digital wallets over traditional banking by considering primary as well as secondary data.
\end{abstract}

Keywords- Economy, E-wallets, financial institution, Analyzing, Infusing

\section{INTRODUCTION}

India is the one of the fastest growing economy of the country. And to support this fast pace of change we should have a strong fincial sector or banking sector which has the capability to infuse the right amount of money to thr economy at the right time. To grow at this pace the country should have free flow of fund which is ensured by the banking sector. As the country progresses the customer preferences and the market condition also changes so in order to keep the level of competence they have to adapt to those changes. And this is applicable to all the industry in the economy. One such innovate changes was the digital wallet. Where the customer can do all the banking transaction linking it their repective banks from the comfort of their home. Digital wallet is the widely adopted means of transaction in the modern India. Where Indian is pacing to become 5 trillion economy and where the government is encouragingdigital payments.The government of India is encouraging to adopt digital form of payment under various schemes. And for which digital wallet is considered as the most suitable alternative for replacing fund transactions. Digital wallets not only provide a platform for making fund transactions but also many other useful services to the customers. They are designed in such a way that all the necessary services required by the customers are present in one place itself. It includes booking of air tickets, bus tickets, movie ticket, ordering food online, recharging phone bills, paying electricity bills. These wallets provide fund backs to the customers which makes the customers the ultimate gainers.

\section{BANKING SYSTEM IN INDIA}

Banking system marked a beginning in India in the $18^{\text {th }}$ century with the introduction of Bank of Hindustan in the year 1770. After bank of Hindustan ended their operation General Bank of India was set up which also failed in 1791. Imperial Bank of India came into the fail market with a merger of three banks Bank of Calcutta, Bank of Bombay, Bank of Madras in the year 1921. After independence it was renamed as the State Bank of India (SBI). The largest public sector bank in India. At that point of time they were awarded the status of central bank of the country until Reserve Bank of India Act came into force in 1934 which lead to the setting up of Reserve bank of India as the central bank of the country to monitor and regulate the finance sector of the economy. After that there was series of merger of the public sector banks with SBI and the recent one is the merger of SBT with SBI.

Reserve Bank of India is the controlling author of the finance sector. They are responsible for the monitoring and regulation of this sector. RBI has the authority to determine the loan rates, deposit rates, repo rate, reverse repo rates, fund reserve ration, statutory reserve ratio. In the board of $\mathrm{RBI}$ there will be two government representatives in order to present the governments interest in it. All the major decision is taken by the concern of the central government. The branches of the banks and ATM's of the banks can be opened only with the prior permission from RBI. RBI provides loans to the banks as well as the government as per their needs.

The digital wallets to start their operation in India need permission from RBI and they will be under the close watch from them.

Digital wallets of the banks also come under the preview of the RBI. RBI governor is selected by the central government authorities. The RBI revises it's polices as the changes in the market situations and alter it in such a way that we are able to get the maximum benefit out of it. (as shown in chart 1)

\footnotetext{
Revised Manuscript Received on September 14, 2019.

Vaishnavi.S, Ph.D research scholar and Assistant Professor(Email: vaishnavis@skasc.ac.in)

Shreyas.Sumesh.Menon,Student(Email: shreyasmenon99@gmail.com)

Vishnu Priya.B, Assistant Professor(Email: vishnupriyab@skasc.ac.in)

Dr.C.Dhanalakshmi, Head and Assistant Professor(Email: dhanalakshmic@skasc.ac.in)
} 


\section{TRADITIONAL BANKING SERVICE}

Banks operates in the market which is fast changing and in order to retain and grow their market share they have to constantly adapt to the changes of the market and customer preference. The service offered by banks has constantly kept pace with the changes in the market. They introduced

- Cheque facility,

- Debit cards,

- Credit cards

- $\quad$ Automated Tiller Machine

- Interbank Transfer

But in any of this service the customer has to make a physical move to incite the transactions. So the banks went in for advancement in technology the online banking service. Where the customer can incites the transaction without any physical movement. But the digital wallets introduction stood as a major thread to the banks. Which further lead to the introduction of digital wallets by banks.

Some of the digital wallets of banks are:
1. ICICI Pocket
2. HDFC Payzapp
3. Citi Master Pass
4. YONO SBI

\section{DIGITAL WALLET}

Digital wallet most popularly known as "e-wallet" refering to the online service for making electronic transaction by an individual. These wallets can be used to purchase online or from store. Now a day's most of the store are providing the felicity of wallet payment The credentials have been passed to the merchant's terminal wirelessly through Near Field Communication (NFC).

In a wallet the customer are not required to fill the details again and again all the data's are stored and is automatically updated into the respective fields across the merchant sites. The information is encrypted by a private software code and merchants are protected against fraud while using digital wallet. Wallets are available free of charge to the customers but the vendors are charged a specific percentage for every transaction they make. These wallets offer fund back offers in the transaction performed by the customers which attract more customers for using these wallets.

In India Paytm wallet is leading market share holder. The wallets not only provide fund transactions but also services as a single point for all the customer requirements.

Some of the Digital Wallets in India are

$\begin{array}{ll}\text { 1. } & \text { Paytm } \\ \text { 3. } & \text { Google pay } \\ \text { 4. } & \text { Amzon Pay } \\ \text { 5. } & \text { Mobikwik } \\ \text { 6. } & \text { BHIM Axis Pay } \\ \text { 7. } & \text { Airtel Money } \\ \text { 8. } & \text { Jio Money } \\ \text { 9. } & \text { TAG-ITI Wallet } \\ \text { 10. } & \text { Freecharge } \\ \text { 11. } & \text { Ola Money } \\ \text { 12. } & \text { Mswipe } \\ \text { 13. } & \text { Vodafone M-Pesa } \\ \text { 14. } & \text { Oxigen }\end{array}$

\section{Citrus Pay}

16. MonoeXpress

\section{OBJECTIVES}

- $\quad$ To study the new value creations of Digital Wallet in the market.

- To know about the success rate of introducing Digital Wallet into the market.

- To know the attitude of customers towards Digital Wallet over Traditional Banking.

\section{DATA COLLECTION}

The primary data has been collected by distributing questionnaire to the respondent to get more relevant information about the product. Convenient sampling method has been used to collect the data. The secondary information was taken from the websites which had published the data required about the product.

Chart 1

The banks in India are classified as follows

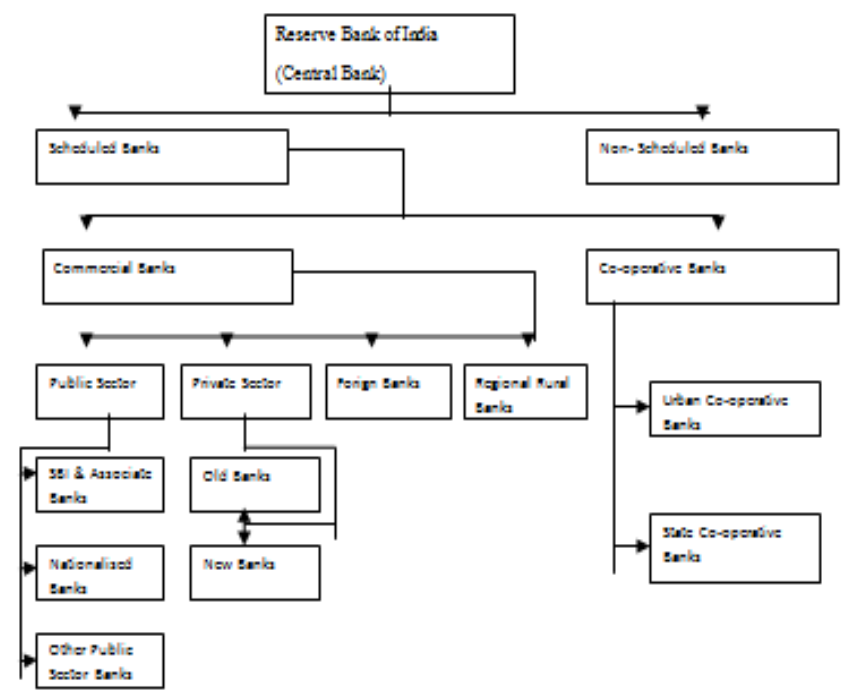

VII. COMPARATIVE BETWEEN DIGITAL WALLET AND TRADITIONAL BANKING

\begin{tabular}{|c|c|c|}
\hline S.No & Digital Wallet & $\begin{array}{l}\text { Traditional } \\
\text { Banking }\end{array}$ \\
\hline 1. & $\begin{array}{l}\text { Transaction can be initiate } \\
\text { from any place }\end{array}$ & $\begin{array}{l}\text { Have to reach out } \\
\text { to bank to initiate } \\
\text { transaction }\end{array}$ \\
\hline 2. & $\begin{array}{l}\text { Less procedures to be } \\
\text { followed to make a payment }\end{array}$ & $\begin{array}{l}\text { Set procedures has } \\
\text { to followed for } \\
\text { making a payment }\end{array}$ \\
\hline 3. & $\begin{array}{l}\text { Real time money transfer can } \\
\text { be done }\end{array}$ & $\begin{array}{l}\text { Money gets } \\
\text { credited only after } \\
\text { a particular period } \\
\text { of time }\end{array}$ \\
\hline 4. & $\begin{array}{l}\text { Provides additional services } \\
\text { apart from banking operations }\end{array}$ & $\begin{array}{l}\text { Only involved in } \\
\text { providing banking } \\
\text { services. }\end{array}$ \\
\hline 5. & $\begin{array}{l}\text { Provide fund back in certain } \\
\text { transactions }\end{array}$ & $\begin{array}{l}\text { No cash back is } \\
\text { provided }\end{array}$ \\
\hline
\end{tabular}




\section{ANALYSIS OF ADOPTION ON DIGITAL} WALLET IN INDIA USING PRIMARY DATA

Table 1 The Respondents Characteristics and Demographic Information

\begin{tabular}{|l|l|l|}
\hline Characteristics & Frequency(n) & Percentage(\%) \\
\hline Gender & & \\
Male & 40 & 80 \\
Female & 10 & 20 \\
\hline Total & 50 & 100 \\
\hline & & \\
Age & & \\
$20-30$ & 17 & 34 \\
$30-40$ & 21 & 42 \\
$40-50$ & 12 & 24 \\
\hline Total & 50 & 100 \\
\hline & & \\
Salary & & 20 \\
$10,000-20,000$ & 10 & 50 \\
$20,000-30,000$ & 25 & 30 \\
$30,000-40,000$ & 15 & 100 \\
\hline Total & 50 & \\
\hline & & 20 \\
Years of Experience & 10 & 28 \\
$<2$ & 14 & 52 \\
\hline 2 to 3 & 26 & 100 \\
3 to 4 & 50 & \\
\hline Total & & \\
\hline & & \\
\hline & & \\
\hline
\end{tabular}

In the above table where $80 \%$ of the respondent were male and rest $20 \%$ were female. They were all categorist into three main sections namely on the bases of age, salary, and years of experience. On the bases of age $42 \%$ of them belonged to 30-40 years age group followed by 20-30 years and $40-50$ years with $34 \%, 24 \%$ respectively. Futher on the bases of salary they earned 20,000-30,000 topped the list with $50 \%$ of them belonging to this section, $30 \%$ in 30,000 40,000 section and $20 \%$ in $10,000-20,000$ section. And on the bases of work experience $52 \%$ of the respondent had a work experience of 3 to 4 years, a bit little $28 \%$ of the respondent with a work experience of 2 to 3 years and merely $20 \%$ having a work experience less than 2 years.

Table 2

\begin{tabular}{|l|l|c|c|}
\hline S.No & Statement & Mean & Stander Deviation \\
\hline 1. & $\begin{array}{l}\text { How do you rate Digital Wallet over Traditional } \\
\text { Banking }\end{array}$ & 3.98 & 0.74 \\
3. & $\begin{array}{l}\text { Rate Digital Wallet on the bases of convinces in } \\
\text { transaction } \\
\text { Rate Digital Wallet on the bases of safety of } \\
\text { transaction. } \\
4 .\end{array}$ & $\begin{array}{l}\text { Rate Digital Wallet over Traditional Banking on } \\
\text { the bases of additional services provided by them. }\end{array}$ & 4.32 \\
\hline
\end{tabular}




\begin{tabular}{|l|l|}
\hline 5. & $\begin{array}{l}\text { Is small and medium shops in your locality } \\
\text { accepting digital wallet payment. }\end{array}$ \\
6. & $\begin{array}{l}\text { Do you think cash back in Digital wallets is } \\
\text { attracting customers towards it }\end{array}$ \\
\hline
\end{tabular}

\section{ANALYSIS OF ADOPTION ON DIGITAL WALLET IN INDIA USING SECONDARY DATA \& RESULTS}

Figure 1

Market penetration of mobile wallets $\wedge$

Trended, regionally

॥12017

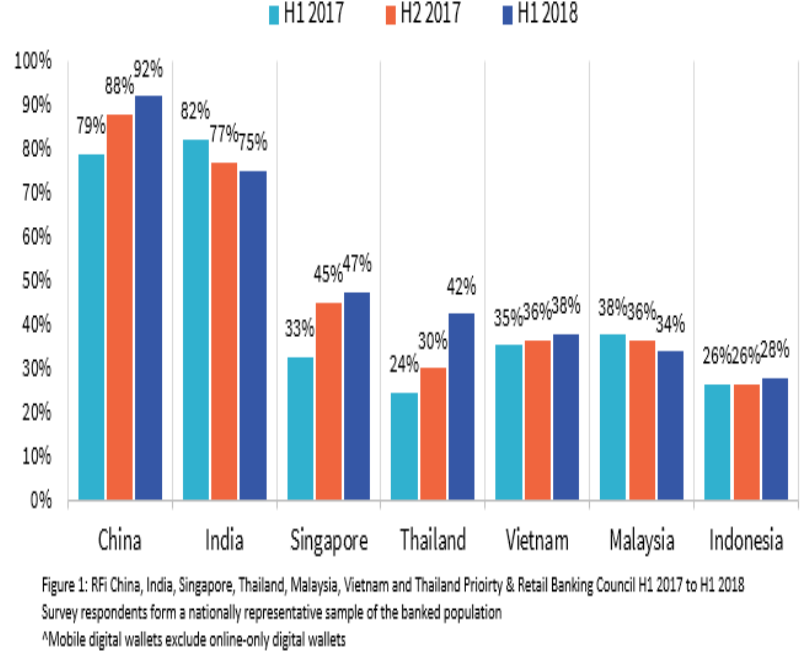

Figure 2

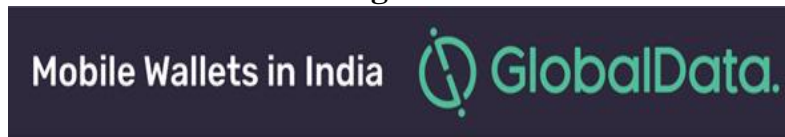

Mobile wallet market growth post demonetization

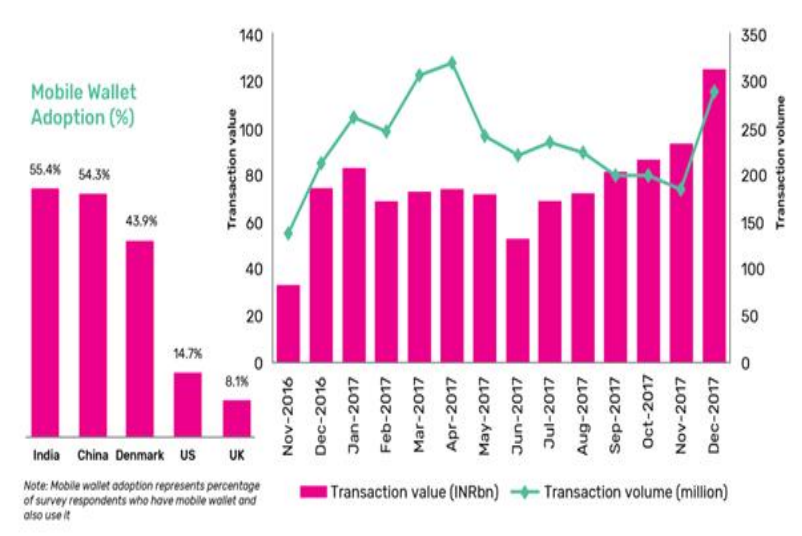

Sources: GlobalData's 2017 Consumer Payments Insight Survey \& Reserve Bank of India

\section{FINDINGS}

* From the primary data, the tables indicate the respondents expressed positive attitude towards the above statement because their means are above the mean of scale of 3 .

* From the secondary data, Figure 1- the figure it is clear that after China, India has largely adopted the usage of digital wallet. The penetration of digital wallet in India is at the average of $78 \%$ in 2017.

\begin{tabular}{|l|c|}
\hline 3.75 & 0.29 \\
4.45 & 0.78 \\
\hline
\end{tabular}

* From the secondary data, Figure 2- From 2016 to the end of 2017 the transaction volume as well as transaction value using digital wallet has gone up. And Indian is leading the chart by $0.1 \%$ more than China.

\section{SUGGESTIONS}

- The banks should consider bringing their own digital wallets.

- $\quad$ The banking operations should be made online with high end security and accessibility.

\section{CONCLUSION}

In a fast growing economy like India,where each and every thing is going digital and online. And in a country where the Government itself is promoting online and digital wallet transactions and even taking various incentives for doing the same. It's high time that the banks reconsider their way of working and $g$ digital. Sinces the people are opting the digital wallet transactions $\mathrm{n}$ a wide rate, it might prove a difficult situation for the bans to survive in the market with their present sort of operations. Day after day the transaction happing through digital wallet is increasing at the same time banking transaction is reducing. So, it's most preferred to step by step transfer all the banking operations to digital.

\section{REFERENCE \\ 1. https://en.wikipedia.org/wiki/Bank \\ 2. https://en.wikipedia.org/wiki/Digital_wallet \\ 3. https://marketbusinessnews.com/financial- glossary/digital-wallet/ \\ 4. https://www.google.com/search?q=images \\ 5. https://www.investopedia.com/terms/b/bank.asp}

